\begin{tabular}{|c|c|c|c|}
\hline Demographics and baseline characteristics & INX & CT-P13 & \\
\hline Total number of RA patients PPS/FAS & $30 / 39$ & $30 / 38$ & \\
\hline Age (years) mean (SD) & $59.9(11.5)$ & $60.4(11.4)$ & \\
\hline Females & $31(79 \%)$ & $25(66 \%)$ & \\
\hline Duration of ongoing infliximab treatment (years) mean (SD) & $8.2(3.7)$ & $9.9(3.4)$ & \\
\hline Concomitant immunosuppressive medication & $27(69 \%)$ & $34(89 \%)$ & \\
\hline ACPA pos & $25(83 \%)$ & 20 (74\%) & \\
\hline Disease worsening & & & $95 \% \mathrm{Cl}$ of group difference after 52 weeks \\
\hline All study patients & $53(26.2 \%)$ & $61(29.6 \%)$ & $-12.7-3.9 \%$ \\
\hline RA & $11(36.7 \%)$ & $9(30.0 \%)$ & $-20.3-29.3 \%$ \\
\hline \multicolumn{4}{|l|}{ Change in disease measures from baseline } \\
\hline Physician Global Assessment of Disease Activity (0-10) & $-0.1(1.3)$ & $0.1(1.4)$ & $-0.58-0.68$ \\
\hline Patient Global Assessment of Disease Activity (0-10) & $1.1(1.4)$ & $0.4(1.9)$ & $0.21-1.91$ \\
\hline $\log _{10}$ erythrocyte sedimentation rate $(\mathrm{mm} / \mathrm{h})$ & $0.0(0.3)$ & $0.0(0.3)$ & $-0.08-0.16$ \\
\hline $\log _{10}$ C-reactive protein (mg/L) & $0.1(0.3)$ & $0.0(0.5)$ & $-0.11-0.22$ \\
\hline DAS28 & $0.2(0.9)$ & $0.2(0.9)$ & $-0.30-0.50$ \\
\hline TEAE (FAS) & 94 & 62 & \\
\hline
\end{tabular}

Data are $\mathrm{n}(\%)$, mean (SD) or median (25-75 percentiles). $95 \% \mathrm{Cl}, 95 \%$ confidence interval of the adjusted treatment difference. DAS28, Disease Activity Score in 28 joints. FAS, Full Analysis Set. PPS, Per Protocol Set. TEAE, treatment emergent adverse events.

endpoint was disease worsening according to disease-specific composite measures and/or consensus between investigator/patient leading to major treatment change. Exploratory subgroup analyses examined disease worsening and safety in RA. The primary endpoint was analysed using logistic regression, adjusted for diagnosis and disease duration.

Results: Demographics, occurence of disease worsening, change in disease measures and treatment-emergent adverse events (TEAE) were similar (Table). Serum drug levels for INX and CT-P13 were similar throughout the study (Figure)

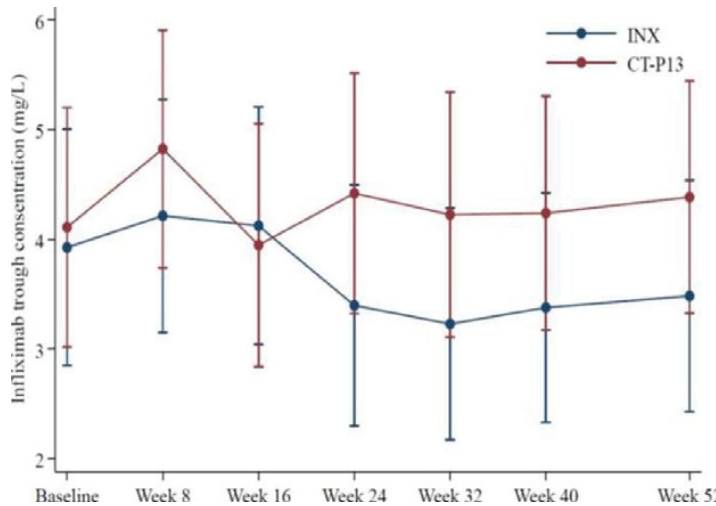

Conclusions: Explorative analyses in the NOR-SWITCH study showed similar efficacy, serum drug levels and safety in RA patients switched to CT-P13 as those on continuous INX. The study was not powered to show non-inferiority within each diagnosis.

References:

[1] Jørgensen $\mathrm{KK}$ et al Switching from originator infliximab to biosimimlar CT-P13 compared to maintained treatment with originator infliximab (NOR-SWITCH): a 52-week randomized double-blind non-inferiority trial. The Lancet, in press.

Disclosure of Interest: G. Goll Consultant for: Orion Pharma, Pfizer, Novartis, Boeringer Ingelheim, AbbVie, I. Olsen: None declared, N. Bolstad: None declared, K. Jørgensen Consultant for: Intercept, Celltrion, Tillot, M. Lorentzen: None declared, C. Mørk Consultant for: Cellgene, AbbVie, Novartis, LeoPharma, ACOhud, Galdena Nordic, J. Jahnsen Consultant for: OrionPharma, Celltrion, Pfizer, MSD, AbbVie, Takeda, NappPharma, AstroPharma, E. Haavardsholm Consultant for: AbbVie, UCB, Roche, MSD, Pfizer, T. Kvien Consultant for: Biogen, BMS, Boehringer Ingelheim, Celltrion, Eli Lily, Epirus, Hospira, Merckserono, Novartis, Orion Pharma, Pfizer, Sandoz, UCB

DOI: 10.1136/annrheumdis-2017-eular.2319

\section{FRI0183 ASSESSING ADHERENCE OF RA PATIENTS TREATED WITH ETANERCEPT USING ETANERCEPT SERUM TROUGH CONCENTRATIONS AND PATIENT SELF-REPORT}

E. Vogelzang ${ }^{1}$, R. Hebing ${ }^{2}$, M. Nurmohamed ${ }^{1}$, M. L'Ami ${ }^{1}$, C. Krieckaert ${ }^{1}$, G. Wolbink ${ }^{1,3} \cdot{ }^{1}$ Rheumatology; ${ }^{2}$ Rheumatology, Pharmacy, Amsterdam Rheumatology and immunology Center / Reade; ${ }^{3}$ Immunopathology, Sanquin Research and Landsteiner Laboratory, Amsterdam, Netherlands

Background: The EULAR recommendations for the management of rheumatoid arthritis (RA) update 2013 contained the following research question: "How good is patient adherence to biological agents and can lack of adherence be related to loss of efficacy?" [1]. Limited studies are published in which adherence of RA patients treated with biological disease-modifying anti rheumatic drugs (bDMARDs) has been assessed. Previous studies regarding adherence of RA patients treated with etanercept did not take into account that patients are instructed to temporarily discontinue bDMARDs therapy during e.g. a serious infection. In addition, etanercept concentrations have never been utilized in determining adherence to etanercept in RA patients.

Objectives: The aim of our study was to determine the percentage of nonadherent RA patients treated with etanercept, using etanercept concentrations and patient self-report, and to assess the relationship between adherence and clinical outcome during 52 weeks.

Methods: Non-adherence was defined as an etanercept trough concentration $<0.1 \mathrm{ug} / \mathrm{mL}$ at least once and no valid/medical reason to miss an etanercept dose. In this retrospective cohort study patients visited our clinic at baseline and $4,16,28,40$ and 52 weeks after initiation of etanercept treatment. At baseline and following visits disease activity score of 28 joints (DAS28) was calculated and blood was drawn to measure etanercept concentrations. During each visit patients were asked if they missed an etanercept dose, at which date and for which reason. Remission was defined as DAS28 $<2.6$ at least for two consecutive visits. Low disease activity (LDA) was defined as DAS28 $<3.2$ during a minimal of two consecutive visits.

Results: In total 292 patients were included. Mean age was 53 years (SD 12.7), $82 \%$ was women and median disease duration was 8 years (IQR 3-16). In total 24 patients had an etanercept concentration $<0.1 \mathrm{ug} / \mathrm{mL}$. Most patients had a medical reason to miss an etanercept dose, see table 1 .

Table 1. Reasons for patients to miss an etanercept dose

\begin{tabular}{lc}
\hline Reason & Number of patients \\
\hline Medical & 10 \\
Did not start & 3 \\
Logistical problem & 1 \\
Stopped due to inefficacy & 1 \\
Unknown & 9 \\
\hline
\end{tabular}

Only ten patients $(3.4 \%)$ were non-adherent during the follow-up of 52 weeks. Of the adherent patients 82 out of $282(29 \%)$ reached LDA versus 1 out of 10 non-adherent patients. A total of 127 of $282(45 \%)$ adherent patients achieved MDA versus 3 out of 10 non-adherent patients.

Conclusions: Most patients had a medical reason to miss an etanercept dose. The percentage of patients who are non-adherent to etanercept therapy is very low (3.4\%).

\section{References:}

[1] Smolen JS, Landewe R, Breedveld FC, et al. EULAR recommendations for the management of rheumatoid arthritis with synthetic and biological diseasemodifying antirheumatic drugs: 2013 update. Ann Rheum Dis 2014;73:492509.

Disclosure of Interest: E. Vogelzang: None declared, R. Hebing: None declared, M. Nurmohamed Speakers bureau: Abbvie, Bristol-Myers Squibb, Merck Sharp \& Dohme, Celgene, Pfizer, Roche, Janssen, UCB and Sanofi, M. l'Ami: None declared, C. Krieckaert Speakers bureau: Pfizer and Abbvie, G. Wolbink Grant/research support from: Pfizer, Speakers bureau: Pfizer, UCB and Abbvie DOI: 10.1136/annrheumdis-2017-eular.1652

\section{FRI0184 THE PROFILES OF PATIENTS WITH RHEUMATOID ARTHRITIS ACCORDING TO THEIR BELIEFS IN THEIR BIOLOGICAL DRUGS. ARCO STUDY}

E. Raya ${ }^{1}$, I. Monteagudo ${ }^{2}$, J. Calvo-Alén ${ }^{3}$, G. Salvador ${ }^{4}$,

T. Vázquez-Rodriguez ${ }^{5}$, J. Tovar $^{6}$, T. Salman-Monte $^{7}$, V. Torrente-Segarra ${ }^{8}$

P. Vela ${ }^{9}$, C. Díaz-Miguel ${ }^{10}$, E. Giner ${ }^{11}$, L. Cea-Calvo ${ }^{12}$, N. Lozano-Rivas ${ }^{13}$,

C. Marras ${ }^{13}$. ${ }^{1} \mathrm{HU}$ San Cecilio, Granada; ${ }^{2} \mathrm{HGU}$ Gregorio Marañon, Madrid; ${ }^{3} \mathrm{HU}$

Araba, Vitoria: ${ }^{4} \mathrm{HU}$ Mútua Terrassa, Barcelona: ${ }^{5} \mathrm{HU}$ Lucus Augusti, Lugo: ${ }^{6} \mathrm{HGU}$,

Elche; ${ }^{7} \mathrm{H}$ del Mar, Barcelona; ${ }^{8} \mathrm{H}$ Moisès Broggi-General, Barcelona; ${ }^{9} \mathrm{HGU}$,

Alicante; ${ }^{10} \mathrm{HU}$ Ramón y Cajal, Madrid; ${ }^{11} \mathrm{H}$ Obispo Polanco, Teruel; ${ }^{12} \mathrm{Medical}$

Affairs, Merck Sharp \& Dohme, Madrid; ${ }^{13}$ HCUV Arrixaca, Murcia, Spain

Objectives: To describe profiles of rheumatoid arthritis (RA) patients according to their beliefs in their subcutaneous biological medication (SC). 